Volume 5

Number 1 Defense Symposium Edition

Article 3

8-1-2018

\title{
The Cycles of Defense Acquisition Reform and What Comes Next
}

Andrew Hunter

ahunter@csis.org

Follow this and additional works at: https://scholarship.law.tamu.edu/journal-of-property-law

Part of the President/Executive Department Commons, and the Property Law and Real Estate Commons

\section{Recommended Citation}

Andrew Hunter, The Cycles of Defense Acquisition Reform and What Comes Next, 5 Tex. A\&M J. Prop. L. 37 (2018).

Available at: https://doi.org/10.37419/JPL.V5.I1.3

This Symposia Article is brought to you for free and open access by Texas A\&M Law Scholarship. It has been accepted for inclusion in Texas A\&M Journal of Property Law by an authorized editor of Texas A\&M Law Scholarship. For more information, please contact aretteen@law.tamu.edu. 


\title{
The Cycles of Defense Acquisition Reform and What Comes Next
}

\author{
By Andrew Hunter $\dagger$ \\ I. Cycles in Defense ............................... 37 \\ II. Cyclicality and Acquisition Reform ............ 38 \\ III. The End of the Cost Control Era .............. 40 \\ IV. Congress Turns the Helm on Acquisition \\ REFORM .................................. 42 \\ V. Assessing Priorities in the Current Acquisition \\ Reform Cycle............................... 45 \\ VI. Information Technology is Driving the \\ Acquisition Reform Debate................... 47 \\ VII. Send in the Cloud ........................... 50 \\ VIII. A Continued Focus on Commercial TeChnology

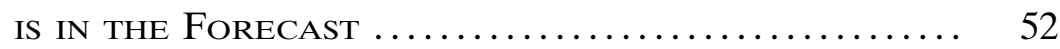 \\ IX. Prospects for the Current and Future

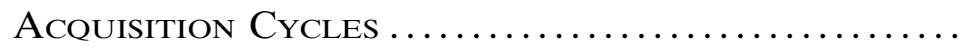

\section{Cycles in Defense}

Many aspects of war and national defense appear to run in cycles. Indeed, the identification and explanation of these cycles is a favorite pastime of military scholars. Historians and political scientists characterize war as alternating cycles of offensive and defensive dominance. ${ }^{1}$ The idea of cyclicality may in fact be hardwired into academic discussions and understandings of war. For example, early war theorist Carl von Clausewitz described an ever-changing character of war undergirded by war's fundamentally unchanging nature. ${ }^{2}$ Because the dominant theoretical understanding of war is that it holds a mixture of both fixed and constantly evolving elements, our concept of war may inherently lend itself to the idea of cycles. At the same time, however, the identification of cycles in war and national defense can be seen empirically. For example, the United States defense budget since World War

$\dagger$ Andrew Hunter is director of the Defense-Industrial Initiatives Group and a senior fellow in the International Security Program at the Center for Strategic and International Studies (CSIS) in Washington, D.C. He focuses on issues affecting the industrial base, including emerging technologies, sequestration, acquisition policy, and industrial policy. From 2011 to November 2014, Mr. Hunter served as a senior executive in the Department of Defense.

1. See Marco Nilsson, Offense-Defense Balance, War Duration, and the Security Dilemma, 56 J. Conflict Resol. 467 (2012).

2. See Christopher Mewett, Understanding War's Enduring Nature Alongside its Changing Character, WAR ON Rocks (Jan. 21, 2014), https://warontherocks.com/2014/ 01/understanding-wars-enduring-nature-alongside-its-changing-character/ [https://per ma.cc/8L3P-57HM] (discussing Clausewitz's distinction between the unchanging nature of war and its changing character over time).

DOI: https://doi.org/10.37419/JPL.V5.I1.3 
II is notoriously cyclical, running through peaks and troughs in constant dollar terms roughly every fifteen to twenty years. ${ }^{3}$ Since peak defense funding periods do not always align with periods of war, it is not the dynamics of war alone that drive cyclical United States defense budgets but a mix of phenomena that includes economic cycles. Hence, in noting the cyclical nature of many aspects of defense, historians must further investigate to determine what dynamics and constraints may be at play in driving the cycle.

\section{Cyclicality and Acquisition Reform}

The acquisition of defense capabilities is an essential component of national defense and one that has generated calls for reform since the beginning of the Republic. United States defense acquisition started with the acquisition of supplies, including food, for the Continental Army and Navy (literal pork barrel spending) that quickly developed an unfavorable reputation. Complaints about the failings of the defense acquisition system, and of the many efforts to reform it, have continued ever since. The young United States government decided to build its first six frigates as a foundation for the United States Navy in the 1790s, which quickly established a pattern that would recur laterall six ships went well over budget and became substantially delayed in delivery. The problems encountered in building the six frigates led to congressional investigations. These ships, however, also proved to be superior in actual combat operations against the world's best navies. ${ }^{4}$ Subsequent acquisition reforms spawned the passage of the False Claims Act during the Civil War to punish those supplying shoddy supplies to the Army of the Potomac, ${ }^{5}$ and the Truman Committee, which targeted war profiteering during World War II. ${ }^{6}$ One of the hallmarks of the long history of defense acquisition reform in the United States from the earliest days of the Republic to today is the sense that we have not solved the problem.

Other authors have observed and studied clear periods or phases of defense acquisition reform in the United States. ${ }^{7}$ This Article ad-

3. See Todd Harrison, Analysis of the FY 2017 Defense Budget, CTR. FOr STRATEGIC \& INT'L STUDIES 11 (2017), https://defense360.csis.org/wp-content/uploads/ 2016/08/Analysis-of-the-FY-2017-Budget.pdf [https://perma.cc/UJJ4-GX7G] (discussing the national defense budget outlay cycles after World War II).

4. See Mark F. Cancian, Cost Growth: Perception and Reality, Def. Acouisition UNIV. (2010), http://www.dtic.mil/get-tr-doc/pdf?AD=ADA523912 [https://perma.cc/ 5RLH-NRGV] (discussing the six frigates and cost growth in defense acquisition generally).

5. See The False Claims Act: A Primer, U.S. DeP’T Just., https://www.justice.gov/ sites/default/files/civil/legacy/2011/04/22/C-FRAUDS_FCA_Primer.pdf [https://perma .cc/KS4J-RXJ3].

6. See The Truman Committee, U.S. Senate, https://www.senate.gov/artandhistory/history/minute/The_Truman_Committee.htm [https://perma.cc/TC33-HXEH].

7. See David L. McNicol \& Linda Wu, Evidence on the Effect of DoD Acquisition Policy and Process on Cost Growth of Major Defense Acquisition Programs, Inst. 
vances the proposition that the progression of defense acquisition reform phases is cyclical-that is, a repeating pattern. This cyclicality occurs because defense acquisition is an effort to balance the enduring elements of acquisition-priorities of cost, schedule, and performance-with the evolving needs of the United States military and the advancing horizons of technology, which are driven by the changing character of war. Cyclicality in acquisition reform, and the dynamics that drive it, can provide insights into the continual frustration with acquisition reform efforts. Acquisition reform creates a cycle of discrete ideas and policy prescriptions, which take turns being au courant. At different times in the acquisition reform cycle, a different acquisition priority predominates, giving rise to related policy prescriptions which are often later undone when the priority shifts. For example, the focus of acquisition reform has shifted over time from the following events: (1) development principles that David Packard promulgated in the $1970 \mathrm{~s} ;{ }^{8}$ (2) to a focus on buying commercial items in the 1990s; (3) to handing off management responsibility to industry through Total Systems Performance Responsibility ("TSPR") or lead system integrator in the 2000s; and (4) to the cost control focus of the Better Buying Power initiative in $2010 .^{9}$ For the defense industry, being in tune with and anticipating these changes in the defense acquisition reform cycle is critical to its business. For many other observers, these policy shifts are exasperating, giving evidence that reform never works and that the government tried every possible policy solution without apparent success.

If acquisition reform is truly cyclical due to the military's shifting needs and competing priorities, however, it might be that acquisition policies often deliver the results they were designed to achieve. However, frequently, those results fail to satisfy us. By the time they arrive, our perceived needs have changed, and we have moved on to a different priority, from a focus on cost, for example, to a focus on speed or performance. In an ideal world, we would shift priorities exactly when circumstances demand. We would optimize the acquisition system to the new ranking of priorities, and we would keep acquisition at the frontier of the Pareto function ${ }^{10}$ that best balances cost, schedule, and

FOR Def. AnAlyses (2014), https://www.acq.osd.mil/parca/docs/ida-p5126.pdf [https:/ /perma.cc/5PCM-QS6F] (discussing periods of acquisition reform after 1970).

8. See Frank Kendall, The Original Better Buying Power-David Packard Acquisition Rules 1971, Def. AT\&L Mag. 2 (May-June 2013), http://dau.dodlive.mil/files/ 2013/06/Kendall.pdf [https://perma.cc/XGS8-6UZW].

9. See J. Ronald Fox, Defense Acquisition Reform, 1960-2009: An Elusive Goal, U.S. Army CTr. MiL. Hist. (2011), https://www.hbs.edu/faculty/Publication\%20Files/ 11-120_e628824d-3f2d-45bc-9c07-f5b056955e50.pdf [https://perma.cc/H944-LEJ8].

10. See G. Agrawal, et al., Intuitive Visualization of Pareto Frontier for Multi-Objective Optimization in n-Dimensional Performance Space, Am. Inst. Of AeronauTICS AND Astronautics (2004), https://pdfs.semanticscholar.org/63dd/ea17dbecfc43 042d6ddc15803824e35cfab9.pdf [https://perma.cc/WK4C-GCYA] (discussing Pareto optimality and visualizing a Pareto frontier). 
performance. In the real world, it is likely that the acquisition system is slow to respond to shifting priorities, meaning that although we may be operating at the Pareto frontier, we are not getting the results we desire. ${ }^{11}$ We may also operate well inside the Pareto frontier for extended periods due to weaknesses in the government's acquisition workforce and/or the industrial base that undermines acquisition performance irrespective of the nature of the policy regime. In this model of cyclical acquisition reform, there is likely to be substantial dissatisfaction with the acquisition system much of the time, even during periods when it is operating at the Pareto efficiency frontier and in accordance with the duly established policy priorities of prior regimes.

\section{The End of the Cost Control Era}

The current situation with defense acquisition reform provides an interesting case study in these dynamics, as it clearly reflects a major priority shift that signals the beginning of a new phase in the cycle. Starting in 2008 through approximately 2014, cost control was the central priority of acquisition reform. Congress embraced this priority with the passage of the Weapon Systems Acquisition Reform Act of 2009 ("WSARA"). WSARA focused on the following initiatives: (1) ensuring the development of independent cost estimates of major defense acquisition programs; (2) understanding the risk in weapons development; and (3) making trade-offs between cost, schedule, and performance. ${ }^{12}$ Likewise, the Department's internal Better Buying Power initiative featured several elements that focused on cost control, including increased use of competition and fixed price contracting, as well as implementation of cost targets. ${ }^{13}$ The passage of the Budget Control Act of 2011 and the triggering of budget cuts through sequestration in 2013 only reinforced the focus on cost control as the major priority in the acquisition system. ${ }^{14}$

11. In fact, a CSIS study of acquisition reform found that results from policy changes generally lag policy implementation by at least two years. Rhys McCormick, Measuring the Outcomes of Acquisition Reform by Major DoD Components, CTR. FOR STRATEGIC \& INT'L STUD. 54 (2015), https://www.csis.org/analysis/measuring-outcomes-acquisition-reform-major-dod-components [https://perma.cc/J33R-7C75].

12. See David J. Berteau, et al., Implementation of the Weapon Systems Acquisition Reform Act of 2009: A Progress Report, CTr. For Strategic \& InT'L Stud. (2010), https://www.csis.org/analysis/implementation-weapon-systems-acquisition-reform-act-2009 [https://perma.cc/92KF-NDQV].

13. See DoD's initial implementation memo for the Better Buying Power Initiative at Better Buying Power: Mandate for Restoring Affordability and Productivity in Defense Spending, U.S. DeP'T Def. (June 28, 2010), https://www.ustranscom.mil/dbw/ docs/BBP_USD_Memo_Acquisition_Professionals.pdf [https://perma.cc/7QBE-EK $\mathrm{HN}]$.

14. It is important to acknowledge that the Department of Defense and the defense acquisition system are both large and sophisticated enough to work towards multiple priorities at the same time. During the period from 2005-2014, DoD was also successfully working to rapidly acquire capabilities to fulfill urgent operational needs for the wars in Iraq and Afghanistan. This effort was critically important not only for 
Starting in about 2014, however, acquisition priorities began a significant shift due to concerns raised by Department of Defense ("DoD") leaders, stating that potential competitors such as Russia and China were catching up with the United States and that the United States technological advantage was eroding. ${ }^{15}$ The earlier focus on cost control inadequately addressed this problem, and in some respects, could even be viewed as potentially inhibiting the development of a next generation of technology. Inside the DoD, this shift took the form of an update to the Better Buying Power Initiative known as Better Buying Power 3.0. In this update, the Department emphasized sharing information between the DoD and industry on the development of and investment in new technologies; removing barriers to the utilization of commercial technologies; and making defense systems easier to upgrade through an engineering approach known as modular open systems architecture. ${ }^{16}$ The DoD also embarked on developing a Long-Range Research and Development plan to guide efforts at recapturing areas of technological advantage. Much of the focus was systemic and long term, laying a foundation to deliver or recapture advantages five to ten years down the line. In order to demonstrate progress on a more rapid timeline, the DoD also created a new organization, the Defense Innovation Unit Experimental ("DIUx"). The DIUx engages in outreach with the rapidly growing technology sector in Silicon Valley and other non-traditional defense contractors who might deliver solutions developed to meet more rapid entrepreneurial timelines. ${ }^{17}$ The DoD also revealed the existence of the relatively new Strategic Capabilities Office ("SCO"), which focused on doing rapid demonstrations and prototyping of new systems-usually ones that took a less traditional or cost-imposing approach to defeating enemy capabilities. ${ }^{18}$ SCO's approach stood in

its operational impacts but also because it demonstrated the ability of the acquisition system to operate with speed and agility when given that mandate. However, rapid acquisition, and the practices followed to implement it, were largely confined to meeting urgent operational needs, a fairly narrow subset of defense acquisition, and speed was not adopted as a systematic priority during this period of time.

15. See David Alexander \& Andrea Shalal, Hagel Announces Push to Boost U.S. Military's Technological Edge, ReuTERs (Nov. 15, 2014, 7:13 PM), https://www.reut ers.com/article/us-usa-defense-hagel-innovation/hagel-announces-push-to-boost-militarys-technological-edge-idUSKCN0J000B20141116 [https://perma.cc/V7X5-QG7N].

16. For a discussion of Better Buying Power 3.0, see Andrew Philip Hunter and Denise E. Zheng, Better Buying Power 3.0: DoD's New Plan for Technical Excellence and Innovation, CTR. FOR STRATEGIC \& INT'L STUd. (Apr. 10, 2015), https://www.csis .org/analysis/better-buying-power-30-dods-new-plan-technical-excellence-and-innovation [https://perma.cc/6ZHU-2FHN].

17. The beginnings of DIUx are described in Fred Kaplan, The Pentagon's Innovation Experiment, MIT Tech. REV. (Dec. 19, 2016), https://www.technologyreview .com/s/603084/the-pentagons-innovation-experiment/ [https://perma.cc/TQT9-ZV QB].

18. The origin and purpose of SCO are explained in Cheryl Pellerin, DoD Strategic Capabilities Office is Near-Term Part of Third Offset, DoD News (Nov. 3, 2016), https://www.defense.gov/News/Article/Article/995438/dod-strategic-capabilities-off 
contrast to typical defense programs that focus on building expensive multi-mission systems designed to combat the full range of threats presented by our most capable adversaries.

\section{Congress Turns the Helm on Acquisition Reform}

However, the close coordination between the DoD and Congress that characterized the WSARA era did not carry over smoothly as this acquisition reform shift occurred. While Congress agreed with the DoD that the erosion of the United States technological advantage was real and sought to accelerate implementation of modular open systems architecture, it did not find satisfaction with the policy approach taken by the DoD. As another key solution to the acquisition reform problem, Congress reshaped and reduced the size of offices in the Pentagon that manage the acquisition system. Congress's priority quickly shifted from ensuring that the DoD had the systematic discipline necessary for cost control, exemplified by the mandates included in WSARA, to a priority on speeding up acquisition decision making by removing decision making layers.

In the Fiscal Year 2016, Congress began this process of removing decision making layers in the National Defense Authorization Act ("NDAA") by statutorily delegating final authority for approving major investment programs like Navy ships, Army fighting vehicles, and Air Force jets, so-called milestone decision authority, from the Secretary of Defense's office down to acquisition officials in the Army, Navy, and Air Force. In the Fiscal Year 2017 NDAA, Congress then mandated that the central acquisition authority in the Office of the Secretary of Defense ("OSD"), the Under Secretary of Defense for Acquisition, Technology, and Logistics, be split up into two offices. The first office focused on developing a culture of rapid and strategic innovation at the DoD, the Under Secretary of Defense for Research and Engineering, and the second office focused on setting policy guidance for purchasing and sustaining major weapon platforms, the Under Secretary of Defense for Acquisition and Sustainment. The details of how these new offices would divide their responsibilities, which had previously been part of a unified organization, were largely left for the DoD to decide. However, these new offices still had to meet a congressional requirement focused on reducing the size of the headquarter's offices in the DoD by 25 percent, meaning that the two new offices created would be significantly smaller than the one office they replaced. ${ }^{19}$ The DoD argued against making these changes as

ice-is-near-term-part-of-third-offset/source/GovDelivery/ [https://perma.cc/5R7S-8C $\mathrm{XE}$.

19. For a discussion of how the creation of the USD R\&E and USD A\&S was adopted and the mandate for $25 \%$ reduction, see DoD Plan to Split Acquisition Duties, EvERYCRSREPORT (Aug. 18, 2017), https://www.everycrsreport.com/reports/IN 10755.html [https://perma.cc/BA9Q-7J4Q]. DoD's plan for the new organizational 
they moved through the legislative process, but ultimately accepted the division of acquisition functions in the final legislation presented to and signed by President Obama. ${ }^{20}$

Other acquisition changes in this period reflected a more cooperative approach between the DoD and Congress, including changes designed to expand the DoD-funded prototyping and advanced component development and to ease access to commercial items which require little to no specialized development for use in military applications. In Fiscal Year 2017, the NDAA mandated the creation of special funds ${ }^{21}$ and oversight boards within each military department ${ }^{22}$ to support the development of prototypes and weapon system components. This approach seeks to create a separate management structure for activities in the middle stages of the technology development cycle. The middle stages occur after promising new technologies are pioneered but before they are integrated into a traditional development program as part of an overall system design and enter production. ${ }^{23}$ The intent was to support technologies as they transition across the so-called "valley of death" between laboratory and factory with the goal of allowing for the increased maturation of technologies before the DoD incorporates them into weapon system designs. ${ }^{24}$ In addition to fostering technology through bettering its chances of survival in transition, this structure is intended to allow technology to develop more independently and aggressively from the existing program structure. Because the acquisition system has been organized almost entirely around large acquisition programs, formally known as major

structure submitted to Congress in August, 2017 can be found at Report to Congress Restructuring the Department of Defense Acquisition, Technology and Logistics Organization and Chief Management Officer Organization, MilitaryTimes (Aug. 2017), https://ec.militarytimes.com/static/pdfs/embargoed-section-901-fy-2017-ndaa-report .pdf [https://perma.cc/QJ56-FG8X].

20. For DoD reaction to the split-up of AT\&L, see Aaron Mehta, Frank Kendall on the NDAA and the End of AT\&L, DEF. NEws (Dec. 3, 2016), https://www.defensenews.com/digital-show-dailies/reagan-defense-forum/2016/12/03/frank-kendall-onthe-ndaa-and-the-end-of-at-1/ [https://perma.cc/K5GP-32WK]. For DoD's response to milestone decision authority delegation, see Scott Maucione, Kendall Voluntarily Loosens Grip on Some Acquisition Powers, Fed. News Radio (Sept. 18, 2015, 5:49 $\mathrm{PM}$, https://federalnewsradio.com/defense/2015/09/kendall-voluntarily-loosens-gripacquisition-powers/ [https://perma.cc/W8VZ-G53D].

21. See National Defense Authorization Act for Fiscal Year 2017, Pub. L. No. 114$328, \S 804$, 130 Stat. 2000, 2250-51 (2016) (originally the House bill created separate funds for each military department, but the final version of the legislation created subaccounts for the military departments within an existing but previously dormant fund known as the Defense Modernization Account).

22. See DoD 101: Overview of the Department of Defense, U.S. DeP't Def., https:/ /www.defense.gov/About/DoD-101/ [https://perma.cc/7565-HSRB] (last visited Aug. 9, 2018).

23. See National Defense Authorization Act for Fiscal Year $2017 \S 806,130$ Stat. at $2256-60$.

24. See Anthony Davis \& Tom Ballenger, Bridging the "Valley of Death", DeF. AT\&L MAG. 13-17 (Jan.-Feb. 2017), http://dau.dodlive.mil/files/2016/12/Davis_Bal lenger.pdf [https://perma.cc/B4N6-ZBTV]. 
defense acquisition programs, there are currently limited resources available to carry forward technologies that demonstrate success in the early stages of development independent of these major programs. Additionally, because there is a limited capacity for risk-taking in major investment programs, this system creates something of a disincentive for the adoption of technologies that have only recently been developed. Implementation of this new management structure for technology development, however, remains somewhat nascent.

Congress created pathways that allow the military departments to bypass the traditional acquisition program structure entirely. In Section 804 of the Fiscal Year 2016, NDAA created the authority for these alternative acquisition pathways, specifying the creation of a pathway for rapid prototyping and a pathway for rapid fielding. In the Fiscal Year 2017 NDAA, Congress exempted programs utilizing these alternative acquisition paths from coverage under the traditional oversight regime, known as the DoD Instruction 5000.02. ${ }^{25}$ Congress left it to the DoD to fill in the details about how this alternative system would operate differently from the traditional acquisition system. This open-ended legislative approach gives the DoD maximum flexibility in designing alternative processes, but also makes it less likely that the DoD will successfully overcome the inherent inertia associated with doing things outside of regular order. The DoD did not raise objections to these systemic changes relating to technology development and alternative acquisition pathways, but it initially approached the task of implementing them fairly slowly. And up until the latest budget request, for Fiscal Year 2019, little to no funding has been allocated by either the DoD or the congressional appropriations committees for either the service-level technology development funds or a rapid prototyping fund created by Congress.

Another recent development in acquisition reform concerns accessing commercial technology. The DoD and Congress spent much of the cost control period of acquisition reform focused on tightening the definition of commercial items and increasing requirements for contractors to supply cost data to justify their pricing. In the last several NDAAs, Congress passed several provisions designed to make it easier to price and purchase commercial items. In order to streamline existing processes for acquiring commercial technology, Congress clarified the process for deciding whether to use streamlined procedures in buying commercial items (known as a commercial item determination $)^{26}$ particularly for systems previously purchased as com-

25. See Ashton Carter, Operation of the Defense Acquisition, U.S. DEP'T DEF. (Nov. 26, 2013), https://www.acq.osd.mil/fo/docs/DSD\%205000.02_Memołoc.pdf [https://perma.cc/VSA6-YT4Y].

26. See generally Claire M. Grady, Guidance on Commercial Item Determinations and the Determination of Price Reasonableness for Commercial Items, U.S. DEP'T DEF. (Sept. 2, 2016), http://www.acq.osd.mil/dpap/policy/policyvault/USA003554-16- 
mercial items. They made clear that the intellectual property rights for commercial items, a key element of ensuring that companies receive a return on their investment in these technologies, remains with the commercial supplier. Congress also limited the DoD's ability to request data on costs for commercial items. Finally, Congress authorized the DoD to use streamlined commercial items procedures for militarypurpose non-developmental items from non-traditional defense suppliers.

\section{Assessing Priorities in the Current Acquisition Reform Cycle}

With the change of leadership at the Pentagon after the Presidential transition in 2017, the DoD's approach to congressionally-mandated acquisition reform changed as well. For example, incoming officials embraced the congressional changes that the DoD previously resisted by delegating oversight of almost all current acquisition programs to the military departments. ${ }^{27}$ And while dramatic moves such as the near total delegation of Major Defense Acquisition Programs ("MDAPS") to the military departments show the sharp change in the DoD's approach, more systemic changes emerged slowly due to the new administration's extended timeline in appointing acquisition leadership positions. Now, however, the team is largely set, including the following: Under Secretary of Defense for Research and Engineering Michael Griffin, Under Secretary of Defense for Acquisition and Sustainment Ellen Lord; Assistant Secretary of the Army for Acquisition, Logistics, and Technology Bruce Jette; Assistant Secretary of the Navy for Research, Development, and Acquisition James "Hondo" Geurts; and Assistant Secretary of the Air Force for Acquisition William Roper. These officials have made extensive comments, identifying their priority as the speed in the development and deployment of new technology. ${ }^{28}$ In addition, the National Defense Strategy ("NDS") issued by Secretary of Defense Jim Mattis early in 2018, identified a strategic imperative in preparing for competition with potential peer

DPAP.pdf [https://perma.cc/W4K8-YS6B] (an overview of commercial item determination).

27. See generally Aaron Mehta, Policy Shift: DoD is Pushing Major Program Management Back to the Military, Def. News (Dec. 11, 2017), https://www.defensenews.com/pentagon/2017/12/11/policy-shift-dod-is-pushing-major-program-management-back-to-the-military/ [https://perma.cc/A789-8Q7Y] (explaining the evidence of the different approach to milestone decision authority delegation in the Trump Administration).

28. See Lisa Fernandino, Speedier Acquisition Needed to Stay Competitive, Defense Official Says, U.S. DeP'T DeF. (Mar. 6, 2018), https://www.defense.gov/News/Article/ Article/1459494/speedier-acquisition-needed-to-stay-competitive-defense-officialsays/ [https://perma.cc/EW5V-Q42C]; see also Caroline Houck, 'Surprising Capabilities' Guru Tapped to Lead Air Force Acquisition, Def. One (Jan. 4, 2018), https:// www.defenseone.com/business/2018/01/surprising-capabilities-guru-tapped-lead-airforce-acquisition/144940/ [https://perma.cc/EH7W-SLZ8]. 
competitors such as China and Russia. The NDS called for an expanded effort to foster and implement innovation, including accessing non-traditional private sector partners as part of a National Security Innovation Base. The heavy emphasis on peer competitors in the DoD's strategic guidance may result in new investments in traditional high-end combat capabilities such as hypersonic missiles, heavy tanks, and artillery systems.

While the combination of new policy direction from Congress, new rhetoric from acquisition leaders, and new strategic guidance are moving the DoD away from the prioritization of cost control, it remains less clear which priority is taking its place in the lead position. Both schedule and performance appear to have their champions for being today's top acquisition priority. It bears noting that trying to identify the new leading priority for acquisition reform is not to suggest that the acquisition system has to, or in fact does, respond to only one priority at a time. In fact, a major thesis of this Article is that the acquisition system must necessarily balance the competing priorities of cost, schedule, and performance. But different policy approaches will dominate depending on how they strike this balance, and how these priorities are ranked relative to one another. And the question of how the DoD and Congress rank the priorities, and whether the two ranking methods are aligned, is of central importance.

The final answer on our current balance of priorities is likely to emerge over time, but a compelling signal comes from examining recently implemented acquisition policy measures and the acquisition debates to which those policies are responding. The strong emphasis in these new acquisition policies and debates is the push for expanded rapid prototyping, technology transition and insertion, and access to commercial technology. These policies are more consistent with a push for increased acquisition speed than they are with a push for cutting-edge performance. The historical parallels offered by acquisition reform cycles of the 1990s reinforce this evidence. In that time, the DoD was coming off of the Reagan defense build-up of the 1980s that focused heavily on expanding the Navy fleet and fielding the advanced systems conceived in the 1970s, such as the Army's Big Five weapon systems ${ }^{29}$ and the B-2 bomber. In response to the Reagan-era acquisition challenges, the Packard Commission recommended consolidating the acquisition authority and the acquisition chain of command under the Under Secretary of Defense for Acquisition. ${ }^{30}$ In the

29. See generally Andrew Hunter \& Rhys McCormick, The Army Modernization Imperative: A New Big Five for the Twenty-First Century, Ctr. FOR STrategic \& INT'L STUD. (May 31, 2017), https://www.csis.org/analysis/army-modernization-imperative [https://perma.cc/XM58-T4QV] (a discussion of the Army's Big Five; the Abrams tank, Bradley Fighting Vehicle, Blackhawk Helicopter, Apache Helicopter, and Patriot Air Defense System).

30. David Packard, et al., A Quest for Excellence: Final Report to the President, President's Blue Ribbon Comm'n on Def. Mgmt. xxiv (June, 1986), https://www 
1990s, the new Under Secretary's signature policy initiative focused on leveraging the commercial market's efficiencies to reduce timelines, improve quality, and limit unique costs in defense acquisition. ${ }^{31}$ This initiative took fruition with the passage of the Federal Acquisition Streamlining Act of 1994 ("FASA"), much of which was embodied in Federal Acquisition Regulation Part 12, designed to put in place a preference for buying commercial items and to streamline their purchasing. ${ }^{32}$

The current focus on streamlining access to commercial technology shortly after a focus on reengineering institutional controls in the acquisition chain of command suggests that the acquisition system is undergoing a policy transition cycle very similar to one that it experienced in the late 1990s. This cycle, however, is more of a reinterpretation than a rerun since the character of war and the technology needed to fight it has changed. This time, the focus on accessing commercial technology is less about using commercial parts as a means of cost and quality control, and more about tapping into innovation in the commercial market, particularly commercial information technology ("IT"). These dynamics were most prominent in the acquisition reforms included in the Fiscal Year 2018 NDAA and other emerging acquisition debates in the last year.

\section{Information Technology Is Driving the Acquisition Reform Debate}

In the most recent year, the efforts to change the acquisition of IT accounted for much of the energy in acquisition reform. From general matters of software acquisition and development, to online marketplaces, to cloud computing and artificial intelligence, acquisition of IT is energizing the discussion for the need for accelerated acquisition processes and access to commercial technology in military applications. ${ }^{33}$

The most controversial debate of the Fiscal Year 2018 NDAA was House Armed Services Committee Chairman Mac Thornberry's pro-

.documentcloud.org/documents/2695411-Packard-Commission.html [https://perma.cc/ 4SMV-74ZN] [hereinafter The Packard Commission].

31. See Jacques Gansler \& William Lucyshyn, Commercial-off-the-Shelf (COTS): Doing it Right, Ctr. For Pub. Pol'y \& Priv. Enter. (Sept. 2008), http://www.dtic .mil/dtic/tr/fulltext/u2/a494143.pdf [https://perma.cc/SBA2-GC3R] (discussing the importance of purchasing commercial items written by the then Under Secretary of Defense for Acquisition, Technology, and Logistics Jacques Gansler).

32. See Ronald Falcone \& Jean Lohier, The Formation, Evolution, and Devolution of Commercial Items Acquisition in the U.S. Federal Government, Contract MGMt. (May 2015), https://www.ncmahq.org/docs/default-source/default-document-library/ $\mathrm{m} /$ articles/cm0515-12-21 [https://perma.cc/D7XN-NVWN] (discussing the history of FASA and commercial item purchasing procedures).

33. See Darrell Issa, Crafting 21st Century IT Reform, NextGov (Sept. 20, 2012), https://www.nextgov.com/cio-briefing/2012/09/commentary-crafting-21st-century-it-reform/58234/ [https://perma.cc/PL4K-G229]. 
posal to provide the DoD with the authority to establish one or more online marketplaces to facilitate the kind of business-to-business purchases that are increasingly prevalent in the private sector. ${ }^{34}$ For example, a DoD buyer would potentially be able to use such an online marketplace to purchase commercial artificial intelligence applications for use with sensitive military data, or to acquire commercially available tools for repairing military aircraft. The proposal somewhat resembled an existing online marketplace the CIA created for the intelligence community. ${ }^{35}$ The proposed marketplace would be designed to ease the DoD's access to commercial products and technology, a partially realized goal of FASA. Under the proposal, once an online marketplace was certified for the program, buying from that marketplace would complete the following: satisfy the requirement for competition; meet the definition of purchasing a commercial item; and ease the process of determining fair and reasonable pricing, domestic content, and fulfillment of small business standards. ${ }^{36}$ During the debate of the Fiscal Year 2018 NDAA on the House floor, the proposal was expanded to become an online marketplace for the entire federal government administered by the General Services Administration ("GSA"), which already serves as a central hub for acquisition of commercial items through a mechanism known as the Federal Supply Schedule. ${ }^{37}$

Chairman Thornberry's online marketplace proposal proved controversial because of a perception that the comprehensive nature of the marketplace, as well as the streamlined process advantages it offered, could compromise opportunities for competition in federal ac-

34. Jake Jedlicka, NDAA Commercial Marketplace Proposal Could Herald Big Changes to Procurement Landscape, FedBID (Aug. 11, 2017), http://www.fedbid.com/ blogs/ndaa-commercial-marketplace-proposal-could-herald-big-changes-to-procurement-landscape [https://perma.cc/YKM9-4UUD]; see also STAFF OF H.R. COMM. ON Armed Servs., 115th Cong., The Nat'l Def. Authorization Act 211 (2017) (establishing the online marketplaces).

35. See Frank Konkel, CIA is bringing Amazon's Marketplace to the Intelligence Community, Nextgov (Feb. 10, 2015), https://www.nextgov.com/it-modernization/ 2015/02/cia-bringing-amazons-marketplace-intelligence-community/104937/ [https:// perma.cc/WZ6U-5L38] (describing the CIA's online marketplace).

36. See U.S. Small Bus. Admin, Size Standards, SBA, https://www.sba.gov/contracting/getting-started-contractor/make-sure-you-meet-sba-size-standards/what-aresmall-business-size-standards [https://perma.cc/96UQ-MVVC] (last visited Aug. 8, 2018) (providing an overview of small business contracting requirements). See Kate M. Manuel, et.al., Domestic Content Restrictions: The Buy American Act and Complementary Provisions of Federal Law, Cong. Res. SERv. (Sept. 12, 2016), https://fas.org/ sgp/crs/misc/R43354.pdf [https://perma.cc/Z3E5-SCE3] (discussing domestic content requirements); see also Competition in Contracting Act (CICA), ACQNotes, http:// acqnotes.com/acqnote/careerfields/competition-contracting-act-cica [https://perma.cc/ VV6C-8SGY] (last visited Aug. 8, 2018) (overview of competition requirements under the Competition in Contracting Act).

37. See Jake Jedlicka, What's Happening With the NDAA Mandated Marketplace?, FedBID (Jan. 18, 2018), http://www.fedbid.com/blogs/whats-happening-with-the-ndaamandated-marketplace [https://perma.cc/S76B-F2CR]. 
quisition. In other words, many feared that the marketplace itself would become a monopoly provider of commercial products and services to the government. ${ }^{38}$ Further, concerns existed that the company operating the marketplace could use the knowledge of pricing and government customer interests to its advantage in other areas of government acquisition. A handful of existing online markets that provide similar services to the federal government on a smaller scale were concerned that the new marketplace would take away their businesses, which did not benefit from the process streamlining authorities provided in Chairman Thornberry's proposal. The final legislation addressed these concerns by deferring the program by two years; mandating that the program include multiple marketplaces operated by more than one provider; using the two-year delay to let the Director of the Office of Management and Budget and GSA develop an implementation plan for the online marketplace; and requiring the Comptroller General of the United States to review and comment on the implementation plan. Some of the lessons of this debate include the following: (1) the process of creating large federal online marketplaces for commercial products and services will continue; (2) the controversies surrounding this proposal will be litigated again as the implementation plan is developed and reviewed; and (3) addressing the complexities of government procurement associated with small business contracting, competition requirements, and security are not easily eliminated by use of more commercial mechanisms.

Another central controversy in the debate over acquisition provisions in the Fiscal Year 2018 NDAA related to a series of proposals by the Senate Armed Services Committee to modify the DoD's approach to software acquisition. ${ }^{39}$ These provisions were designed to: (1) direct the DoD to obtain access to original source code and related technical data when funding the development of software; (2) pilot the use of agile developmental approaches for both major software development programs and some software-intensive warfighting systems; (3) use open source approaches to developing government-funded software and attempt to reverse engineer legacy source code; and (4) commission the Defense Innovation Board ${ }^{40}$ to do a year-long study on software acquisition. Much of the controversy over these provisions

\footnotetext{
38. See Tim Cooke, When Amazon Meets Defense Acquisition, Def. One (Aug. 14, 2017), https://www.defenseone.com/business/2017/08/when-amazon-meets-defense-acquisition/140233/ [https://perma.cc/97YD-8MKW].

39. See Billy Mitchell, Senate NDAA Gives Marching Orders for Pentagon's JEDI Cloud, FEDSCOOP (June 6, 2018), https://www.fedscoop.com/senate-ndaa-jedi-clouddefense-department-pentagon-dod/ [https://perma.cc/YM5Q-SRG9].

40. The Defense Innovation Board is a federal advisory committee created under the leadership of former Secretary of Defense Ash Carter that advises the Department of Defense on issues of innovation. See Cheryl Pellerin, Carter to Implement 3 Recommendations from Defense Innovation Board, U.S. DeP'T Def. (Oct. 28, 2016), https://www.defense.gov/News/Article/Article/989582/carter-to-implement-3-recommendations-from-defense-innovation-board/ [https://perma.cc/XQ5L-T69N].
} 
related to the hard mandates they established for the DoD and defense contractors, such as requiring them to always deliver original source code to the government as part of the government's statutory rights in technical data and requiring that all unclassified governmentfunded software must be included in a public open source repository.

The final legislation retained the basic thrust of these provisions, generally modifying the language from strict mandates to preferences, guidelines, or criteria for consideration in contract negotiations. It is notable that these provisions focused on government-funded software development and not the acquisition of commercially-developed software. This may be somewhat counter-intuitive given the generally accepted notion that when it comes to IT and software, the commercial sector is well ahead of the government sector. These provisions, however, have more application to commercial software than meets the eye because in many cases, government-funded software builds upon the foundation of commercially-developed software. This complexity fuels intense debate over the intellectual property rights in software and open source requirements because discriminating between government-funded and truly commercial software remains challenging.

\section{Send in the Cloud}

A closely-related controversy emerged over the DoD's plans to purchase cloud computing capability after the Fiscal Year 2018 NDAA debates concluded. One of the signature initiatives of the new leadership team at DoD is a plan to transition the department to cloud capabilities. They established a Cloud Executive Steering Group, lead by most of the DoD's senior leadership, with the intention of accelerating the adoption of "cloud architecture and cloud services with a focus on commercial solutions." 41 The group developed a plan known as the Joint Enterprise Defense Infrastructure ("JEDI") Cloud, under which the DoD will enter into an open-ended contract arrangement ${ }^{42}$ with a cloud provider using a competitive contract process.

The JEDI Cloud contract also demonstrates the propensity for DoD's commercial IT acquisition to cause controversy. One central focus of controversy has been on the DoD's intent to select a single provider for JEDI Cloud. Many in the industry have argued that the

\footnotetext{
41. Accelerating Enterprise Cloud Adoption, U.S. DeP'T Def. (Feb. 15, 2018), https://www.defense.gov/News/News-Releases/News-Release-View/Article/1442705/ accelerating-enterprise-cloud-adoption/ [https://perma.cc/7VME-S8E2].

42. DoD has indicated that it intends to award an indefinite delivery vehicle contract to a single provider using full and open competition. See Frank Konkel, Pentagon Releases Second Draft RFP for Multibillion Dollar JEDI Cloud, Nextgov (Apr. 16, 2018), https://www.nextgov.com/it-modernization/2018/04/pentagon-releases-second-draft-rfp-multibillion-jedi-cloud/147471/ [https://perma.cc/8ZQY-DPLQ].
} 
cloud contract should be awarded to multiple vendors. Echoing the controversy over the proposed online marketplace, this intent to award to a single provider has raised concerns that the JEDI Cloud will establish a monopoly within the DoD for cloud computing, extending major advantages to the winner in the broader government IT market. The JEDI Cloud would be available to every DoD organization interested in making the transition to the cloud, meaning that JEDI could and likely would develop into the largest cloud provider across the Department.

The DoD has argued that it is more efficient to consolidate services on a single cloud platform-a fairly common practice in the commercial sector. It also argues that there are already existing cloud contracts at the DoD that will be left in place, and future cloud initiatives could be carried out independent of the JEDI Cloud. Thus, concerns about a monopoly environment are misplaced.

These and related concerns about the structure of the JEDI Cloud acquisition led Congress to require the DoD to provide two reports on the topic in the first half of $2018 .{ }^{43}$ This controversy illustrates that while Congress and others have urged the DoD to adopt commercial practices, especially for IT, many complications that have traditionally dogged the defense acquisition system, but are largely inapplicable to large commercial concerns, continue to remain prominent. For example, it remains imperative for the DoD to balance its contract awards so that long-term supplier relationships and strategic partnerships do not preclude the ability to have competition in the future.

As the controversy over JEDI Cloud continued raging, on February 7, 2018, another controversy over cloud computing resulted from the announcement of an Other Transaction Authority ("OTA") agreement with REAN Cloud, a commercial cloud provider. This OTA was initially described as being open to all of the DoD users and potentially valued at $\$ 950$ million based upon an expectation of widespread use of the OTA throughout the DoD. ${ }^{44}$ This led to some initial confusion as to whether the award to REAN Cloud was related to the JEDI Cloud effort or had effectively preempted it. As a result, the OTA with REAN Cloud was quickly revised and limited to users of the United States Transportation Command ("TRANSCOM"), and descoped to have an expected total value of $\$ 65$ million.

In fact, the REAN Cloud OTA originated separately from the JEDI Cloud. It was a follow-on agreement to an initial prototype

43. See Frank Konkel, Congress Tells Pentagon to Justify Its Single Cloud Plan, Nextgov (Mar. 22, 2018), https://www.nextgov.com/it-modernization/2018/03/con gress-tells-pentagon-justify-its-single-cloud-plan/146882/ [https://perma.cc/QK9V-FE GK].

44. See Frank Konkel, Pentagon Releases Second Draft RFP for Multibillion Dollar JEDI Cloud, Nextgov (Apr. 16, 2018), https://www.nextgov.com/it-modernization/2018/04/pentagon-releases-second-draft-rfp-multibillion-jedi-cloud/147471/ [https://perma.cc/8ZQY-DPLQ]. 
agreement established with help from the DoD's Silicon Valley office-DIUx. DIUx facilitated a relationship between TRANSCOM and REAN Cloud through a limited prototyping OTA. TRANSCOM awarded the follow-on "production" OTA without further competition pursuant to authorities provided in the Fiscal Year 2017 NDAA. ${ }^{45}$ The Government Accountability Office ("GAO") has subsequently questioned whether using the follow-on production authority was justified, arguing that the follow-on production OTA agreement with REAN Cloud did not meet the requirements of the statutory authority provided in the NDAA. ${ }^{46}$

\section{A Continued Focus on Commercial Technology IS IN THE FORECAST}

The current acquisition policy cycle will continue to focus on acquisition of commercial technology because an important Congressional study streamlining the acquisition process recommends extensive changes in the way the government approaches competition and commercial technology. The project is known as the Section 809 Advisory Panel on Streamlining and Codifying Acquisition Regulations, and it has issued two volumes of a planned three volume set of recommendations for streamlining acquisition. ${ }^{47}$ The Panel's recommendations are detailed and extensive, but perhaps their most meaningful recommendations relate to the acquisition of commercial technology. Conceptually, the Panel calls for a major shift in how the DoD approaches the marketplace on the front end of the acquisition process. The recommendations are designed to facilitate increased consideration of commercial technology solutions to military needs.

Today's defense acquisition process tends to begin with extensive internal analysis of military needs, such as repurposing existing assets and analyzing alternative approaches to acquiring new systems. This analysis defines a detailed statement of the DoD's requirements which is then sent out to industry. While there is often discussion with industry during these early phases of the acquisition process, the request for proposals ("RFP") to meet the DoD's detailed requirements is what

45. National Defense Authorization Act for Fiscal Year 2017, Pub. L. No. 114-328, $\$ 806,130$ Stat. 2000, 2259 (2016) (discussing this authority as provided in Section 2447d of Title 10 of the United States Code as added by Section 806 of the Fiscal Year 2017 NDAA).

46. See Ralph O. White, Press Statement on Bid Protest filed by Oracle, U.S. Gov't AcCountABILITy OfF. (May 31, 2018), https://www.gao.gov/press/oracle_bid_ protest.htm [https://perma.cc/3VFU-GHEA] (discussing GAO's findings in a bid protest against the OTA award filed by Oracle).

47. See Section 809, SEc. 809 PANEL, https://section809panel.org [https://perma.cc/ 4MXM-TWBA] (last visited Aug. 21, 2018) (explaining that Section 809 Advisory Panel on Streamlining and Codifying Acquisition Regulations was established pursuant to Section 809 of the FY 2016 NDAA for the purpose of reviewing defense acquisition regulations, and the statutes on which they are based, to develop detailed recommendations for streamlining the acquisition process). 
industry is formally asked to respond to. These RFPs are usually issued on a federal-acquisition-only portal known as FedBizOps that is not closely monitored by suppliers who seldom do government work. Further, the large quantity of mandatory DoD requirements in these RFPs significantly narrows the potential competitors to a handful or less. The Section 809 Panel argues for “changing DoD's competitive procedures to compete solutions to problems, rather than assess a company's ability to meet detailed technical specifications," thereby shifting "away from spending extensive time defining and validating requirements, to using more challenge-based competitions or taking advantage of available market solutions to quickly develop and field new capabilities." 48

Described as the "the dynamic marketplace," this approach would encourage a broader range of companies to engage with the DoD by offering solutions to military problems before the solution is tightly defined in a way that lends itself to purpose-built military systems. Although not explicitly stated by the Section 809 Panel, its recommended approach could facilitate an existing preference for the procurement of commercial items that has existed in federal regulation since the FASA's passage, but which may have been a preference in name only for most defense contracting purposes. ${ }^{49}$

The Section 809 Panel also recommends that the government should significantly streamline the transaction rules in the acquisition process that apply to existing products and services and those that require customization short of significant new development. ${ }^{50}$ This will further incentivize commercial sector firms and other non-traditional suppliers to participate more broadly in defense acquisitions. While the specific measures the Section 809 Panel recommends for implementing its dynamic marketplace approach will be included in the yet-

48. Report of the Advisory Panel on Streamlining and Codifying Acquisition Regulations, SEC. 809 PANEL 8 (2018), https://section809panel.org/wp-content/uploads/ 2018/01/Sec809Panel_Vol1-Report_Jan18_FINAL.pdf [https://perma.cc/HG8N-BK 2Z].

49. See generally Jen Judson, Judge Rules in Favor of Palantir in Lawsuit Against US Army, Def. News (Oct. 31, 2016), https://www.defensenews.com/land/2016/10/31/ judge-rules-in-favor-of-palantir-in-lawsuit-against-us-army/ [https://perma.cc/KT44-9T NU] (discussing a 2016 ruling in the U.S. Court of Federal Claims in the case Palantir USG v. United States, 129 Fed. Cl. 218 (2016), that preemptively terminated a source selection process for the Army's Distributed Common Ground System program because the court found that the Army had not meaningfully considered whether Palantir's commercial product could meet its requirements).

50. Report of the Advisory Panel on Streamlining and Codifying Acquisition Regulations, SEC. 809 PANEL (June 2018), https://section809panel.org/wp-content/uploads/ 2018/06/Sec809Panel_Vol2-Report_June18.pdf [https://perma.cc/Y9YW-T9Y5]. The Section 809 Panel credits a report from the Center for a New American Security for its categorization of commercial technology applicable to military needs. The report is contained in Ben Fitzgerald, et al., Future Foundry: A New Strategic Approach to Military-Technical Advantage, CTR. FOR NEw AM. SEC. (2016), https://www.cnas.org/ publications/reports/future-foundry\%2520 [https://perma.cc/RH26-RHQN]. 
to-be-issued third volume of its recommendations, one indication of congressional interest in the Panel's recommendations relating to commercial technology is the inclusion of several Section 809 Panel's proposed changes to clarify statutory definitions of commercial items in the House-passed version of the Fiscal Year 2019 NDAA. The full recommendations of the Section 809 Panel will be ripe for consideration in the Fiscal Year 2020 legislative cycle.

\section{Prospects for the Current and Future ACQuisition Cycles}

While commercial technology continues as a driver of acquisition speed, especially for IT; the decentralization of acquisition decisionmaking and the delegation of decision authority to the military departments will likely encourage different priority balances to emerge in different sectors of the acquisition system.

The delegation of acquisition authority to the United States Army has resulted in a significant internal reorganization of its acquisition functions. ${ }^{51}$ The Army is, for the first time, establishing a command focused on bringing together the wide variety of acquisition stakeholders in one structure, the Army Futures Command. Army Futures Command will bring the system for deciding requirements for new capabilities together with the acquisition process. In effect, the Army consolidates acquisition responsibilities within the service more closely under the control of the Army Chief of Staff, to whom the commander of Army Futures Command will report. ${ }^{52}$ The Army Futures Command will pursue a new modernization strategy, built around six major priorities, and hopes to significantly accelerate the delivery of new capability. ${ }^{53}$ By centralizing responsibility for requirements setting and acquisition execution in one command, the Army

51. The Army's decision to reorganize its acquisition functions would not have been prohibited even if milestone decision authority had not been delegated, but the Army's interest in pursuing this path was likely spurred by the increased responsibility for acquisition placed on the Army Chief of Staff. See David Vergun, US Army Futures Command to Reform Modernization, Says Secretary of the Army, Army News SERv. (Dec. 8, 2017), https://www.army.mil/article/197886/ [https://perma.cc/ BU9D-YDWF].

52. Most of the elements of Army Futures Command previously resided in the Training and Doctrine Command, Army Material Command, Army Test and Evaluation Command, or the Office of the Assistant Secretary of the Army for Acquisition, Logistics, and Technology. For a description, see David Vergun, US Army Futures Command to Reform Modernization, Says Secretary of the Army, Army News Serv. (Dec. 8, 2017). https://www.army.mil/article/197886/ [https://perma.cc/BU9D-YDWF].

53. For a description of the Army's modernization priorities, see Patrick Tucker, US Army Chief Announces Major Reorganization For How Army Develops, Buys Weapons, Def. One (Oct. 6, 2017), https://www.defenseone.com/technology/2017/10/ feeling-rivals-heat-us-army-streamlining-and-centralizing-way-it-buys-weapons/ 141603/ [https://perma.cc/HK8M-VPZD]. 
hopes to reduce the friction (and timespan) of coordinating across the Army's multiple major communities.

By contrast, the United States Air Force plans to extend its delegation of acquisition authority from OSD by redelegating this authority down to program executive officers and empowering program managers. ${ }^{54}$ This redelegation may reflect the relative maturity of the Air Force's major programs, such as the KC-46 tanker and the B-21 bomber, where the high level strategic issues are decided (notably in both cases with cost control as the major priority), and the focus is on program execution. Matters of program execution are often best handled at the program level or as close to it as possible. ${ }^{55}$ However, less mature parts of the Air Force acquisition portfolio, such as recent efforts to design new systems for command and control and systems designed to approach space as a warfighting domain, may use the same decentralized authority to achieve different objectives. Notably, Air Force acquisition executive Will Roper is using the prototyping authority granted by Congress to rapidly demonstrate critical high-performance technologies, such as hypersonic strike systems called for in the National Defense Strategy. ${ }^{56}$

Decentralizing and distributing acquisition authority within military departments may lead to a variety of microcosms within the acquisition system where the balance of acquisition priorities is different. Other trends, however, will impact the acquisition system across its entire scope. Another major trend is the increasing functionality of weapon systems defined by software over hardware. The capability seen in the Air Force's flight lines, in the Army's motor pools, or in the Navy's homeports is increasingly determined by lines of code rather than steel and aluminum.

This trend has major implications for the acquisition system because it presents challenges to its basic structure, which was originally designed around an industrial production model. Software-defined sys-

54. As described in testimony from Air Force Secretary Heather Wilson and cited in Aaron Mehta, Policy Shift: DoD is Pushing Major Program Management Back to the Military, DEF. NEws (Dec. 11, 2017), https://www.defensenews.com/pentagon/ 2017/12/11/policy-shift-dod-is-pushing-major-program-management-back-to-the-mili tary/ [https://perma.cc/VNC8-92LN].

55. For a clear expression of this principle, see DODI 5000.02 Enclosure 13: Urgent Capability Acquisition in Enclosure, AIDA, https://aida.mitre.org/dodi-5000/ rapid-fielding-of-capabilities/ [https://perma.cc/486L-UQYR] (last visited Aug. 21, 2018) (stating "approval authorities for each acquisition program covered by this enclosure will be delegated to a level that promotes rapid action").

56. See Aaron Mehta, Air Force Awards Nearly \$1 Billion Contract for a Hypersonic Cruise Missile, Def. News (Apr. 18, 2018), https://www.defensenews.com/air/ 2018/04/18/air-force-taps-lockheed-for-new-hypersonic-cruise-missile/ [https://perma .cc/ZSK4-7RMZ] (describing the Air Force's effort to field a hypersonic strike weapon); Heather Wilson, Air Force Releases FY17 Air Force Acquisition Report, AnDREws GAZETTE (Mar. 16, 2018), http://www.dcmilitary.com/andrews_gazette/news/ air-force-releases-fy-air-force-acquisitionreport/article_b5eab9ec-a077-5bb2-9f3c-b1b 499b16fe1.html [https://perma.cc/4NHS-WJZ9]. 
tems break down the boundaries around which many organizations and processes are organized. Software-based systems don't graduate from development to production to sustainment like hardware-based systems, presenting challenges to government budgeting mechanisms that are leading to calls for new funding categories that can deal with the iterative nature of software development and production. ${ }^{57}$

Consider the idea that a system which can send and receive electrons may serve many purposes, such as a communications device, a sensor, a weapon, and an electronic defense system. Software-based capabilities are steadily spreading, and they are a powerful reason why Under Secretary of Defense Ellen Lord appointed a special assistant, Jeff Boleng, for software acquisition. Boleng will "help oversee the development of software development policies and standards across DoD and offer advice on commercial software development best practices to Pentagon leadership ...." ${ }^{58}$ Perhaps the perfect embodiment of this trend towards software-driven capabilities is in artificial intelligence. How this trend will affect the balance of acquisition priorities in the future is difficult to predict, but one thing seems likely: change will remain dynamic rather than static, leading to continuous acquisition reform cycles for the years to come.

57. Wilson Brissett, Pawlikowski Says Air Force Needs Faster Software Development, AIr Force MAG. (July 17, 2017), http://www.airforcemag.com/Features/Pages/ 2017/July\%202017/Pawlikowski-Says-Air-Force-Needs-Faster-Software-Development .aspx [https://perma.cc/4XLZ-S4YP].

58. Jane Edwards, Report: Jeff Boleng Named DoD's Special Assistant for Software Acquisition, ExecutiveGov (Apr. 16, 2018), http://www.executivegov.com/ 2018/04/report-jeff-boleng-named-dods-special-assistant-for-software-acquisition/ [https://perma.cc/F99C-RXD6]. 